\title{
PATRICK GEDDES \\ ÉS AZ ORGANIKUS SZEMLÉLET*
}

DR. KESERÜ KATALIN

\begin{abstract}
Mikor a természet élő rendjével való integráció, a világ egységben való látásának és megértésének romantikus törekvése újra kivirágzott, a 19-20. század fordulóján élt Skóciában Patrick Geddes biológus és várostervező. Tevékenységének megidézése a mostani század-, ill. ezredfordulón nemcsak azért aktuális, mert a 20. század kísérletei, a metropoliszokra koncentrált szellemi és tőkebefektetései során az ő gondolatai feledésbe merültek és a befektetésekről mára kiderült: nem időtállóak, ill. társadalmi falanszterhez vezetnek, hanem mert korunkban a Geddest is jellemző organikus szemlélet iránt egyre nagyobb a tudományos érdeklődés. Említhetem Carolina van Eck Organicism in the 19th Century Architecture címú könyvét (1994), Portoghesi legújabban megjelent munkáját az organikus építészetről (Skira) és az ösztöndíjas tanulmányokat Magyarországon is végzett kanadai Olivér Botár 680 oldalas tudománytörténeti és elméleti áttekintését a bioromantikáról, mely Prolegomena to the Study of Biomorphic Modernism: Biocentrism, László Moholy-Nagy's „New Vision” and Ernö Kállai's Bioromantik címmel doktori disszertációnak készült a Torontói Egyetemen (1998).

Tulajdonképpen a Változó eszmék a modern épitészetben címú Peter Collinskönyv (London, 1965) megjelenését megelőző másfél évtizedet jellemezhetjük csak úgy, hogy keveset törődött a modern müvészetek és tudományok életközpontú nagy áramával, amit Collins az építészet „,biológiai analógiájaként” tárgyal, a 18. század közepétől kezdődően. Ez a másfél évtized, úgy tünik, mégis elegendő volt ahhoz, hogy a modern gondolkodást meghatározó új biológia szinte a feledésbe merüljön (talán csak Darwin 1842-es, A fajok eredete című elméletét kivéve),
\end{abstract}

* Szerző előadása a Kós Károly Egyesülés tíz éves fennállásának alkalmából a Budapesti Műszaki Egyetemen szervezett ünnepi ülésen, az 1999. október 3.-ai délutáni programban hangzott el. Az előadás nem a Geddes életmú szakmai körökben legismertebb arculatát (völgy metszet, diagrammok) tárgyalja - e vonatkozásban lásd az Irodalomjegyzéket -, hanem Geddest, mint az angolszász kultúrában születő organikus eszme egyik megteremtőjét mutatja be. A tanulmányt az eseményről történő megemlékezésként közöljük. (Szerk.) 
azokkal a tételeivel együtt, amiket Collins az építészeti gondolkodásban is megtalált. Ezek: a szervek közti korreláció, a szervezetek kapcsolata a környezettel, forma és funkció azonossága, vitalitás. Olivér Botár szerint ezek a múlt századfordulóra világnézetet határoztak meg: a vitalizmusét, ami egymással rokon filozófiákban és tudományos körökben fogalmazódott meg: a bergsoni metafizikában, az életfilozófiában, a németországi monizmusban, a holizmusban, az organicizmusban, biocentrizmusban és még a neo-transzcendentalizmusban is. Ebben a televényben szorosabbá váltak a kapcsolatok a tudományok és múvészetek között. A Jugendstil, az Art Nouveau nem csak nevükben hordozták a vitális energiát, de használták a természeti formákat, s a múvészek építettek az anyagiakkal megteremthető biológiai kapcsolatra (Rodin), sőt, az anyagok-szervezetek belső mozgására (Gaudi), s olykor olyan fizikai felfedezésekre is (energeticizmus), amelyek az univerzum egységét állították (Csontváry Kosztka Tivadar). Az építészek „,szerves" térkapcsolatokat alakítottak ki (Frank Lloyd Wright, Baillie Scott, Victor Horta, Toroczkai Wigand Ede) a mozgásnak megfelelően s a környezettel is összefüggésben, valamint felértékelődött az alkotófolyamat mint élet, mint teremtésanalógia (Worringer: Absztrakció és beleérzés, 1908). Ezenközben az élet/müvészet és helyszíne közti viszony több szempontú elemzésére is sor került, így a regionális, etnikai, vernakuláris és tradicionális értékek felfedezésére. A kultúra egyegy eleme időben és térben szövődő szálaival az élő világorganizmus részeként (szerveként) tekintődött.

Nagy-Britanniában ennek az organikus gondolkodásnak és múvészetszemléletnek sajátos hagyománya volt. John Ruskin a Modern festők című könyvének köteteivel (1845) bevezette a vitális szépség fogalmát az esztétikában, s ezt összefüggésbe hozta a morállal (amennyiben a teljes életre törekvő boldog tevékenység közben születhet meg) és a társadalommal (társadalomkritikával és a társadalom jobbítására vonatkozó elvi javaslatokkal). Teóriáját, az építészetre vonatkoztatva, Az épitészet hét lámpása címü, 1849-ben írt könyvében fejtette ki, majd a Velence kövei köteteiben $(1851,1853)$ olyan termékeny gondolatokkal gyarapította, melyek a koronként meg-megújuló modern múvészetek érvelésének alapjait jelentik. Köztük - a tökéletes múvek utánzásában kimerülő akadémizmus idején - a tökéletességről, befejezettségről szólóval (ami mögött már a gépkorszak törekvései is ott álltak), miszerint ezek önmagukban nem értékek, s éppen nem a „késztermék” a fontos, hanem „elöállításának” folyamata, az alkotófolyamat. Mivel ez egyszerre megértés, megismerés ( az egyetemes, isteni vagy lényegi Szépségé, tulajdonságoké, formáé) és alkotás, nem csak az ún. esztétikai képesség jut benne szóhoz, hanem a külső forma összefüggései a belsővel és a teljességgel. Az alkotó tehát a világot ezen összefüggések folyamatában látja és valósítja meg, az alkotás/múvészet így az egész lét müködése: organikus. 


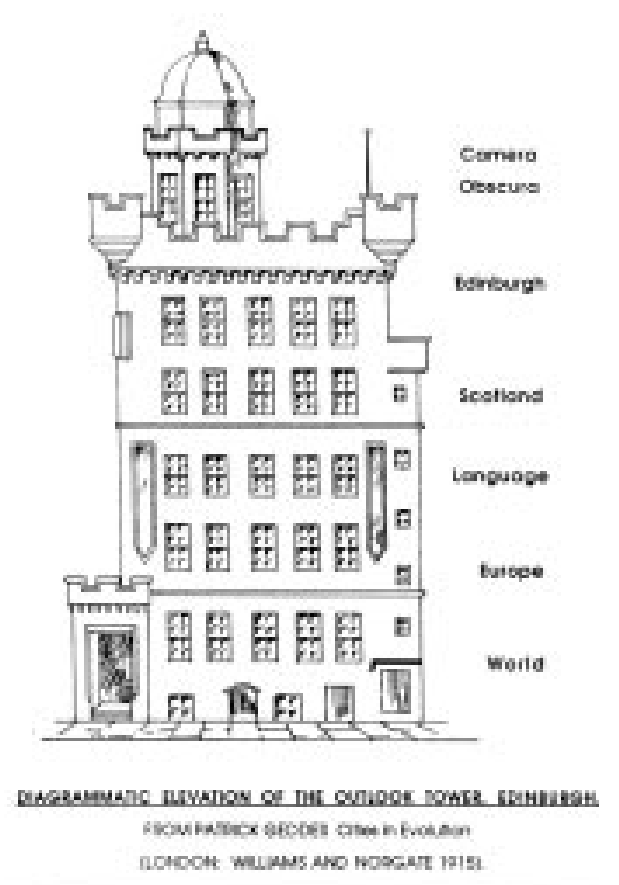

Ruskin e művészetelméletre építette az organikus társadalom elméletét, az így felfogott alkotó/teljes élet általánossá tételét, ami nála - az ipari társadalom tapasztalatai szerint - a munkára, mégpedig a személyes (kézmúves) munkára alapozódott. (Mintaként a középkort emelte ki, amivel együtt járt a helyi építészeti tradíciók, regionális anyagok felfedezése.) Ezzel ugyan előlegezte a szocialista társadalomelmélet kialakulását, annak ember-felfogását (a munka tette emberré az embert), de az akkor még a biológia tudományának eredményeivel ötvöződött. Ruskin fiatalabb kortársa, William Morris a formatervezést, építészetet is tökéletesen organikus tevékenységként fogta fel, mikor az életmód kifejezésének tartotta a funkció és forma azonosságát. Organikus szemlélet és biológiai filozófia (Darwin, majd T. H. Huxley és Herbert Spencer) együtt inspirálták a 19-20. század fordulójának építészetét, ami legkomplexebben a várostervezésben, város-rehabilitációkban bontakozott ki.

Patrick Geddes (1854) Huxley tanítványa volt, s a botanika professzoraként kezdte munkásságát a skóciai St. Andrews Egyetem egyik filiáléjában. Az élet kutatása kezdettől fogva analógiákat kínált neki a társadalom és kultúra életének megértéséhez. S mint utolsó könyve, a Life, Outlines of General Biology (1931) mutatja, az élet volt a központi fogalma, viszonyítási alapja. Ezért hathatott rá az 
ipari forradalom és következményeinek ruskini bírálata, s tekinthette a társadalmi fejlődés alapjának az egyes embert, életkörülményeinek élet-centrikus megteremtését, illetve rehabilitálását. Ruskin kulcsmondata a modern kor, a gépkorszak töredékes emberéről („mindent gyártunk, kivéve embert”) a tárgyak, javak produkálása és tökéletesítése helyett az ember rehabilitálására irányította figyelmét, s ezt a közösséggel, környezetével és kulturális örökségével összefüggésben látta megvalósíthatónak. Mint legutóbbi monográfusa, Helen Meller írja (1990): a haladás 19. századi ideáját alakította át, a jólétért folytatott egyéni küzdelem helyébe a kultúra társadalmi szerepét állítva, kívánva.

Gondolatmenetének modellje saját Edinburgh-i háza volt: a Kilátótorony. Az ötemeletes épület szintjein, lefelé haladva, Edinburgh-tól a nagyvilágig jutott a látogató-tanuló, a régión, az országon, a kontinensen keresztül. Minden szinten az adott térséget bemutató kiállítással, a tetőn a kiindulópontként használt camera obscurával, mely a belátható környék vizuális analízisét nyújtotta. Ez az 1890-es években berendezett múzeum-torony volt ,a világ első szociológiai laboratóriuma". Ugyanis a környezetet az addig szeparált akadémiai tudományokat összefogó új tudomány, a szociológia szerint vizsgálta, feltárva az adott hely topográfiáját, gazdaságát, történelmét és népességének mozgását, foglalkozás szerinti megoszlását. A szociológiai szemléletet Frederic Le Play francia szociológustól kölcsönözte, akinek gondolataival 1878/79-es franciaországi útján találkozott. S mivel az ő társadalomvizsgáló alapkategóriái (hely, munka, család) megfeleltek Geddes biológiai kategóriáinak és összefüggéseiknek (környezet, funkció, organizmus), Geddes használta és továbbfejlesztette azokat. Általuk vált megvalósíthatóvá a „regionális áttekintés”, Geddes szerint mindenfajta jövőépítés kiindulópontja.

Élet és környezet összefüggésében az építés az életminőség javítását jelentette számára. 1885-ben már ennek érdekében alapította - papokkal, építészekkel, tervezőkkel - az Edinburgh-i Társadalmi Egyesülést, aminek három céhe az élet és a környezetformáló múvészetek közti közvetlen kapcsolatot volt hivatva megteremteni, munkások, gyermekek körében, kórházakban és más, hasonló középületekben zenei, kézmúves és kertészkedő foglalkozásokkal, illetve dekoratív szimbolikus falképekkel. Az Egyesüléssel és a Kilátótoronnyal is a szükebb és tágabb világban helyzetét-helyét ismerő, azt összefüggéseiben látó, öntudatos polgárság formálása volt célja, amit a modern társadalom kulcsának tartott. Saját városának környezeti és társadalmi problémái indították el tehát azon az úton, amelyen végül általánosan használható urbanisztikai alapelveket fogalmazott meg.

Ezek legismertebbje s egyúttal a biológus Geddes legsajátosabb ideája a város mint élő organizmus és környezetének (a régiónak) összefüggése. Az ő korában többféle városépítési koncepció létezett az iparosítás következményeitől szabadulni vágyó Angliában. Legismertebb E. Howard kertváros-ideája, ami a nyugati világban (Budapesten is) általánosan elterjedt a századelőn. Emellett a város határait kitoló telepítési koncepció mellett az iparvárosok egészséges lakáskörülményeit 

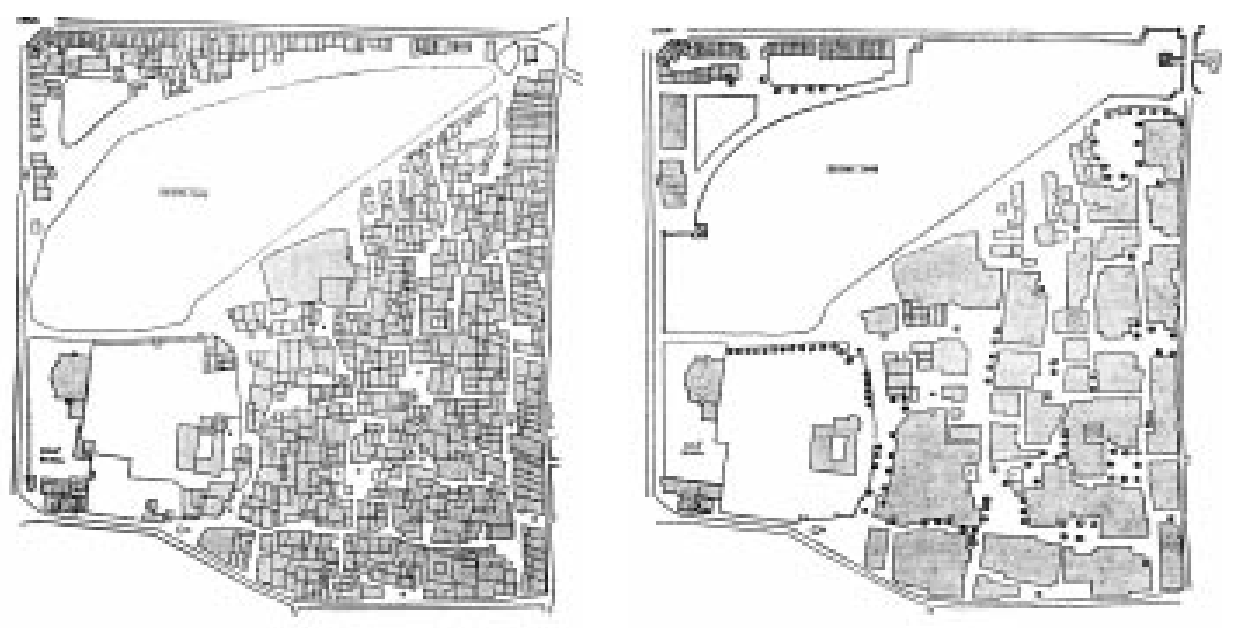

Balrampur

külön övezetekben megteremteni szándékozó tervek voltak még számottevőek. Geddes egy harmadik utat kezdeményezett. Nem a város aktuális szükségleteiből indult ki, jóllehet ezek égetőek és nagyszámúak, ám belterjesek voltak. A városok fejlődésének történetét vizsgálta, hogy rájöjjön „,a fejlődésben lévő élet rendjére”. Ahogy a városok egy-egy régió központjaivá növekedtek, például a görög városállamokban megőrizve a harmonikus egységet város és vidéke közt, úgy a hatalmi központtá lett városok és kiszolgáltatott provinciájuk kapcsolata Geddes korában (és a miénkben) élet- és fejlődésképtelennek tünt. Különösen a milliós nagyvárosok minden eszközt önmaguk gerjesztette igényeik kiszolgálására használták fel, mérhetetlen kulturális (mentális, társadalmi stb.) különbségeket támasztva a város és vidék lakói közt.

Geddes emberi múalkotásnak tekintette a várost - ahogy a magát tanítványának valló Lewis Mumford később megfogalmazta -, forma és funkció egységének, amiben a kulturális szokásokkal együtt teremtődnek meg a külső-belső terek. Benne az életértékek megtartását, mind a lakók mind a város (az organizmus) számára, a legfontosabbnak tartotta. Az élethez pedig a természetes környezet nélkülözhetetlen. Nem mint természetélvezet (fogyasztás), hanem mint interaktív kapcsolat, a földdel való foglalkozás. A kertjét is művelő ember lelkileg, fizikailag és biológiailag kiegyensúlyozott, ép, terményeinek azaz munkájának életértéke van, s ez társadalmi érték is. Korunkban, az elértéktelenedett, eltartott életek korában, amikor az aktív városi lakosság tevékenysége fóként arra irányul, hogy önmaga szükségességét igazolja egy absztrakt civilizáció mesterségesen támasztott igényeit gyarapítva, még értékesebbnek tűnik Geddes ideája a kertjét is müvelő városi polgárról. Különösen azért, mert ezt az ideát komplex urbanisztikai rendszerbe ültette, a városrekonstrukció általános szükségét hirdetve. 
Ez az általa megteremtett átfogó szemlélet biológiára épülve filozófiává növekedett: új humanizmussá az élet megbecsülése alapján, és gyakorlati filozófiává is az ember és környezete összeszervezése útján. Korának regionális szemléletét kiterjesztve úgy vélte, miként a szervezet és környezete elválaszthatatlanok, úgy a népcsoport is attól a helytől, melyen él. A régiók geológiailag, időjárásukat tekintve, földrajzilag stb. különböznek egymástól, különbözőségük-változatosságuk okán egymásra szükségük van (mint ahogy ez így volt a középkorban is). Ez az interaktív kapcsolat tartja életben a régiókat (ahogy Geddes nevezte: városrégiókat), nem a nagyvárosokba koncentrált és kioltott sokféleség. Ezért szükséges a „decentralizáció". Egy-egy városrégió újrakialakítása vagy rekonstrukciója tehát nemcsak a funkcionális helyen, nem is csak az adottságokból kiinduló munkák megtervezése, hanem a hagyományok, szokások ismeretében azok újraszületési lehetőségeinek megteremtése - mindez természetesen a legkorszerübb módon.

Geddes konzervatív beavatkozásnak nevezte azt a módszert, amellyel szociológiai, egészségi szempontból szlömösödő városokat újravitalizálhatónak vélt. Különösen jó okot adtak módszerének kifejtésére az indiai nagyvárosok.

Miközben kiállításokat, konferenciákat szervezett a városról, s azon dolgozott, hogy a Világkultúra Erőforrásainak Intézetét létrehozzák Brüsszelben (az 1890-es években alapított bibliográfiai világközpont mintájára), Madras kormányzója Indiába hívta. Az indiai városok különleges fejlődéstörténete és akkori állapota jó időre lekötötte teljes figyelmét. A városok ugyanis már a pre-ipari korban óriási méretűek voltak: Madras például 1823-ban 817 ezer lakost számlált. A 20. század elején a növekedés áttekinthetetlenné vált, betegségek pusztítottak, nagymérvű volt a gyermekhalandóság, a szlömösödés. A brit gyarmatként élő India és NagyBritannia közti viszony a századfordulón kezdett változni: az angol értelmiség körében terjedt egyfajta indianizmus, spirituális megújulás vágya indiai ihletésre - ez már nem a gyarmatosítók attitüdje volt. A 20. század első évtizedeiben Indiában helyi önkormányzatok váltották fel a brit hivatalnokokat, mellettük viszont sok angol misszionáriusi segítséget nyújtott. Geddes már az 1900-as párizsi világkiállításon megismerkedett India-barátokkal, ismerte azt a misszionáriust is, aki 1912-ben Londonban könyvet jelentetett meg a megújulni vágyó Indiáról. Így az Indiai Nemzeti Kongresszus 1914-es konferenciáján, Madrasban bemutatott kiállítása és előadása meglehetős vihart kavart. Mert India saját tradíciójára építve látta megvalósíthatónak a megújulást. Az új indiai vezetők közül sokan egyetértettek vele. Így Madras fejlesztését rá bízták, mellé építész tervezőt hívtak Angliából, H. V. Lanchastert, a Brit Építészek Királyi Intézetének elnökhelyettesét, a Brit Várostervezési Intézet egyik alapítóját. (A Patrick Geddes in India címü könyv az ő Előszavával jelent meg Londonban, 1947-ben.) Geddes az európai nagyvárosokban kialakult brutális szokás (útszélesítések, útbevágások) helyett - a város mai fogalmaink szerinti rehabilitációja egyféle előkísérleteként - aprólékos munkába fo- 
gott. Házról házra járt, hogy felbecsülje, az össze-vissza toldozott épületek, angol utasításra beépített kertek között hol lehet helyreállítani az eredetileg udvaros-kertes házakat, hol lehet köztük járatokat, tereket nyitni, ezzel a városi kommunikáció útvonalait rekonstruálni, a privát és szakrális kommunikáció helyeit, a köztereket visszaállítani. Ezzel testileg-lelkileg-szellemileg kívánta rehabilitálni az egyes embereket, s rajtuk keresztül a társadalmat.

Hosszú éveket töltött Indiában, maga mellett tudhatta Gandhit és Rabindranath Tagorét, aki vele egybehangzóan mondta: a városi ember figyelme saját életére és munkájára koncentrálódik, ,ezért mesterséges különbséget támaszt önmaga és az egyetemes természet közt, aminek pedig a keblén nyugszik". Geddes kertjeivel, megnyitott és fásított tereivel visszacsempészte a városba a természetet, életadó környezetet, ezáltal a jól-létet. A fejlődésben lévő város, ami kulcsfogalma volt, ezt jelentette: vitális, öntudatos, élő organizmus, amiben állandó az interakció korszerủ tudás, környezet és a történeti értékek közt, mint ahogy ezek együtt, egy népesség kultúrájának állandó interakcióban állnak a várost jellemző téri formákkal.

Geddes meg volt győződve arról, hogy ez az organikus szemlélet fokozatosan legyőzi a mechanikust a világban. Joggal remélte, hiszen kortársai is így vélték. Nálunk a Társadalomtudományi Társaság ülésein vitáztak, a századelőn például Lőw Loránd természetet és társadalmat összekapcsoló előadásán, a Huszadik Század címü folyóirat körében gondolkodtak az organikus szociológiáról (Madzsar Imre), s Somló Bódog írt kora társadalma és a természetes kiválasztás viszonyáról, az egyes emberi szervezet és a többi folytonos interakciójáról (Állami beavatkozás az individualizmusba, 1902). De a „biológiai analógia” az urbanisztikában sem volt ismeretlen. Wildner Ödön 1906-os, kertvárosokról szóló tanulmányában (Huszadik Század) szólt Patrick Geddes első ilyen nagyszabású munkájáról is, a skóciai Dunfermline-ról, a róla 1904-ben kiadott könyv alapján (City Development. A Study of Parks, Gardens and Culture-institutes. A Report to the Carnegie-Dunfermline-Trust). S hamarosan meg is jelennek - igaz, inkább Howard és a Geddessel egy ideig együtt dolgozó Unwin kertvárosaira támaszkodva - a kertvárosok Magyarországon is. Építészeink közül azonban talán csak az „ország-építo”” Kós Károly, az Unwin hampsteadi megoldásait Kispestre ültető építész tudta, hogy a tervezett helyek milyensége a lakók, a népesség mentalitását, életét mekkora mértékben befolyásolja.

\section{IRODALOM}

Patrick Geddes szövegeiből néhány olvasható a Vidor Ferenc által szerkesztett Urbanisztika címü kötetben. Gondolat Kiadó, Budapest, 1979.

A városépítést illetô építészeti elveirôl lásd Meggyesi Tamás: $A$ városépités útjai és tévútjai. Müszaki Kiadó, Budapest, 1985. 


\section{PATRICK GEDDES AND THE ORGANIC IDEAS Summary}

As the organic architecture has emerged in different ways since the late $60 \mathrm{~s}$ in Hungary and has been not only a style but an idea of the rehabilitation of man, its life and environment in the phalanstery of socialist modernism, later on of post-modern consumerism, this paper evokes the work and ideas of Patrick Geddes, organicist town planner of the turn of the century dealing with the "biological analogy" of his work, its Ruskinian sources and organicist contemporaries in arts, his initiatives in the field of the social decentralization and the rehabilitation of the "city region", his methods of recreating the direct contacts between man and nature, one and the others on the basis of traditions, customs and life i.e. the "conservative intervention". The reason of this evocation is the "third way" of the younger contemporary of Geddes, Hungarian Károly Kós, one of the spiritual masters of the organic architects' union, his vernacularism and program of building a country. 